\title{
THE INFLUENCE OF ANTICHOLINERGIC DRUG AND OXIME SELECTION ON THE EFFECTIVENESS OF ANTIDOTAL TREATMENT AGAINST TABUN-INDUCED POISONING IN MICE
}

\begin{abstract}
Jiři Kassa
Purkyně Military Medical Academy, Hradec Králové: Department of Toxicology

Summary: 1. The influence of oximes (pralidoxime, obidoxime, HI-6) and anticholinergic drugs (atropine, benactyzine, biperiden, scopolamine) on the effectiveness of antidotal treatment to eliminate tabun-induced lethal effects was studied in mice. 2. Obidoxime seems to be the most efficacious oxime for the elimination of tabun-induced lethal effects in mice, although the difference in the efficacy of obidoxime and HI-6 is not significant when they are combined with atropine. 3. Obidoxime and HI-6 when combined with centrally acting anticholinergic drugs (benactyzine, biperiden and scopolamine) seem to be more efficacious in the elimination of toxic effects of the lethal dose of tabun than their combination with atropine. 4 . The findings support the hypothesis that the choice of acetylcholinesterase reactivators as well as the anticholinergic drug selection are important for the effectiveness of antidotal mixture in the case of antidotal treatment of tabun-induced acute poisoning.
\end{abstract}

Key words: Tabun; Oximes; Anticholinergic drugs; Acute toxicity; Mice

\section{Introduction}

Despite the entry into force in April 1997 of the Chemical Weapons Convention forbidding the development, production, stockpiling and use of chemical warfare agents, the world has seen a rapid proliferation of such agents (21). The chemical warfare agents include nerve agents, very dangerous highly toxic organophosphorus compounds (OPs) that exert their toxic effects by phosphonylation and subsequent inactivation of acetylcholinesteraserase (AChE, EC 3.1.1.7). The inactivation of this enzyme allows the accumulation of acetylcholine (ACh) in the synaptic terminals of the central and peripheral nervous systems with subsequent widespread overstimulation of cholinergic receptors $(18,25)$. Effective management of nerve agent-induced cholinergic overstimulation is critical for immediate casualty treatment and for a rapid and full recovery from the effects of nerve agent exposure. Unfortunately, certain OPs were found to be resistant to the standard antidotal treatment which consists of anticholinergic drugs to counteract the accumulation of $\mathrm{ACh}$ and oximes to reactivate nerve agent-inhibited AChE $(7,18)$.

Tabun (O-ethyl-N,N-dimethyl phosphoramidocyanidate) is probably one of the most dangerous compounds among the warfare nerve agents, since its deleterious effects are extraordinarily difficult to counteract because of the existence of a lone electron pair located on an amidic group that makes the nucleophilic attack of oximes almost impossible $(4,7,9,11,16)$.

As the ability of currently used monopyridinium (e.g. pralidoxime) and bispyridinium oximes (e.g. obidoxime) to eliminate toxic effects of nerve agents is generally rather low, the $\mathrm{H}$ oximes have been developed to improve the effectiveness of oximes to reactivate nerve agent-inhibited $\mathrm{AChE}$ and eliminate nerve agent-induced lethal effects $(14,17)$. Among the series of $\mathrm{H}$ oximes, the HI-6 has been the most studied because it seems to be the most efficacious oxime, yet found, against toxic effects of soman $(1,12,23)$. Unfortunately, the reactivating efficacy of HI-6 for tabun-inhibited AChE is not so high as in the case of soman poisoning $(5,6,16,22,26,28)$.

Not only the choice of oximes but also the anticholinergic drug selection could influence the effectiveness of antidotes against OPs. The OP-induced poisoning is usually treated by an oxime in combination with the anticholinergic drug atropine. Nevertheless, there are other anticholinergic drugs that seem to be suitable adjuncts to oxime treatment of nerve agent-induced poisoning, especially in the case of poisonings with centrally acting nerve agents such as soman and tabun (26). It has been described that some centrally acting anticholinergic drugs such as benactyzine are able to increase the ability of HI- 6 to eliminate nerve agent-induced lethal toxic effects in comparison with atropine (13). 
The present study compares the effects of currently used oximes (pralidoxime, obidoxime) and $\mathrm{H}$ oximes (HI-6) in combination with various anticholinergic drugs (atropine, benactyzine, biperiden, scopolamine) against tabun-induced acute poisoning in mice.

\section{Methods}

Male mice weighing between 22 and $25 \mathrm{~g}$ were obtained from Konárovice. The animals were maintained in an airconditioned room with light from 07.00 to $19.00 \mathrm{~h}$ and were allowed free access to standard food and tap water. The principles of laboratory animal care were followed and the handling of animals was made under the supervision of the Ethics Committee of Medical Faculty of Charles University and Purkyně Military Medical Academy in Hradec Králové.

Tabun of $95 \%$ purity was purchased from Military Technical Institute Brno. Its purity was assayed by acidimetric titration. The oxime HI-6 of $98.5 \%$ purity was synthesized at the Department of Toxicology of Purkyně Military Medical Academy in Hradec Králové. Its purity was analyzed using HPLC. All other chemicals and drugs of analytical grade were obtained commercially and used without further purification.

In the first part of the experiments, tabun-poisoned mice were treated intramuscularly (i.m.) with one of tested oximes (pralidoxime, obidoxime and the oxime HI-6) at equieffective doses $\left(5 \% \mathrm{LD}_{50}\right)$ in combination with atropine $(21 \mathrm{mg} / \mathrm{kg})$ one minute after the challenge of tabun. In the second part of the experiments, tabun-poisoned mice were treated i.m. with obidoxime or the oxime HI-6 in combination with one of tested anticholinergic drugs (atropine, benactyzine, biperiden and scopolamine). The oxime as well as anticholinergic drugs were used at equieffective doses $\left(5 \% \mathrm{LD}_{50}\right)$.

The effectiveness of tested antidotal mixtures was evaluated by the assessment of the $\mathrm{LD}_{50}$ values and their $95 \%$ confidence limits using probit-logarithmical analysis of death occuring within $24 \mathrm{~h}$ after i.m. administration of tabun at five different doses with six mice per dose (24). The efficacy of tested antidotal mixtures was expressed as protective ratio $\left(\mathrm{LD}_{50}\right.$ value of tabun in protected mice/ $\mathrm{LD}_{50}$ value of tabun in unprotected mice).

Statistical significance was determined by the use of Student's t-test and differences were considered significant when $\mathrm{p}<0.05$.

\section{Results}

The therapeutic efficacy of antidotal mixtures consisting of various oximes in combination with atropine is presented in Table 1. These results show that obidoxime seems to be the most efficacious reactivator of tabun-inhibited $\mathrm{AChE}$ in the elimination tabun-induced lethal effects in mice, although the difference in the efficacy between obidoxime and the oxime HI- 6 is not significant. On the other hand, obidoxime as well as the oxime HI-6 are significantly more efficacious $(p<0.05)$ to protect the mice from the lethal effects of tabun than pralidoxime.

The efficacy of obidoxime or the oxime HI-6 in combination with various anticholinergic drugs is shown in Tables 2 and 3. The data clearly demonstrate the higher effectiveness of centrally acting anticholinergic drugs (benactyzine, biperiden, scopolamine) to eliminate tabun-induced lethal effects in comparison with atropine in the case of the combination of anticholinergic drugs with obidoxime $(p<0.05)$ (Tab. 2). On the other hand, the therapeutic efficacy of the combination of the oxime HI-6 with centrally acting anticholinergic drugs is only slightly higher than the combination of HI-6 with atropine (Tab. 3). In addition, obidoxime appears to be significantly more efficacious than the oxime HI-6 when combined with anticholinergic drugs with pronounced central effects such as benactyzine, biperiden and scopolamine $(\mathrm{p}<0,05)$.

Tab. 1: Therapeutic effect of oximes, administered at a dose of their $5 \% \mathrm{LD}_{50}$ value in combination with atropine (21 $\mathrm{mg} / \mathrm{kg}) 1 \mathrm{~min}$ after poisoning, on the $\mathrm{LD}_{50}$ value of tabun. * significantly different from the untreated group at the level of $\mathrm{p}<0.05,{ }^{\mathrm{x}}$ significantly different from the group treated with pralidoxime at the level of $\mathrm{p}<0.05$.

\begin{tabular}{|c|c|c|}
\hline Treatment & $\mathrm{LD}_{50}(\mu \mathrm{g} / \mathrm{kg}) \pm 95 \%$ IS & Protective ratio \\
\hline- & $275.4(269.3-281.6)$ & - \\
\hline $\begin{array}{c}\text { HI-6 } \\
+ \text { atropine }\end{array}$ & $430.2(414.0-447.1)^{*} \mathrm{x}$ & 1.56 \\
\hline $\begin{array}{c}\text { Obidoxime } \\
+ \text { atropine }\end{array}$ & $454.9(421.8-490.6)^{* \mathrm{x}}$ & 1.65 \\
\hline $\begin{array}{c}\text { Pralidoxime } \\
+ \text { atropine }\end{array}$ & $377.7(355.8-400.9)^{*}$ & 1.37 \\
\hline
\end{tabular}

Tab. 2: Therapeutic effect of obidoxime in combination with various anticholinergic drugs, administered at a dose of their $5 \% \mathrm{LD}_{50}$ values 1 min after poisoning, on the $\mathrm{LD}_{50}$ value of tabun.

* significantly different from the untreated group at the level of $\mathrm{p}<0.05,{ }^{\mathrm{x}}$ significantly different from the group treated with obidoxime and atropine at the level of $\mathrm{p}<0.05$.

\begin{tabular}{|c|c|c|}
\hline Treatment & $\mathrm{LD}_{50}(\mu \mathrm{g} / \mathrm{kg}) \pm 95 \%$ IS & Protective ratio \\
\hline $\begin{array}{c}\text { Obidoxime } \\
+ \text { atropine }\end{array}$ & $275.4(269.3-281.6)$ & - \\
\hline $\begin{array}{c}\text { Obidoxime } \\
+ \text { benactyzine }\end{array}$ & $773.2(636.7-939.1)^{*} \mathrm{x}$ & 2.81 \\
\hline $\begin{array}{c}\text { Obidoxime } \\
+ \text { biperiden }\end{array}$ & $716.9(685.6-749.6)^{*} \mathrm{x}$ & 2.60 \\
\hline $\begin{array}{c}\text { Obidoxime } \\
+ \text { scopolamine }\end{array}$ & $716.9(657.3-780.0)^{*} \mathrm{x}$ & 2.60 \\
\hline
\end{tabular}


Tab. 3: Therapeutic effect of HI-6 in combination with various anticholinergic drugs, administered at a dose of their $5 \% \mathrm{LD}_{50}$ values $1 \mathrm{~min}$ after poisoning, on the $\mathrm{LD}_{50}$ value of tabun.

* significantly different from the untreated group at the level of $p<0.05,{ }^{x}$ significantly different from the group treated with HI- 6 and atropine at the level of $p<0.05$.

\begin{tabular}{|c|c|c|}
\hline Treatment & $\mathrm{LD}_{50}(\mu \mathrm{g} / \mathrm{kg}) \pm 95 \%$ IS & Protective ratio \\
\hline $\begin{array}{c}\text { HI-6 } \\
+ \text { atropine }\end{array}$ & $275.4(269.3-281.6)$ & - \\
\hline $\begin{array}{c}\text { HI-6 } \\
+ \text { benactyzine }\end{array}$ & $462.1(432.6-493.5)^{*}$ & 1.68 \\
\hline $\begin{array}{c}\text { HI-6 } \\
+ \text { biperiden }\end{array}$ & $524.5(503.3-546.6)^{*} \mathrm{x}$ & 1.91 \\
\hline $\begin{array}{c}\text { HI-6 } \\
+ \text { scopolamine }\end{array}$ & $460.2(444.4-476.5)^{*}$ & 1.68 \\
\hline
\end{tabular}

\section{Discussion}

Nerve agents are still considered to be the most important chemical warfare agents. With the existing threat of the use of chemical weapons not only in military conflicts but also in terorristic attacks, the search for effective protection is the central concern of different laboratories both civilian and military $(7,20)$.

The effectiveness of antidotal treatment of acute poisoning with tabun is not sufficient regardless of the choice of the oxime because tabun-inhibited $\mathrm{AChE}$ is very difficult to reactivate $(6,11,22,26,28)$. The reason for the weak reactivation potency of the oximes is not the rate of aging of phosphonylated AChE that is relatively low (10) but the presence of lone electron pair located on an amidic nitrogen. This lone electron pair makes the nucleophilic attack very difficult (9). Therefore, the oxime HI-6, that is rather effective against soman $(12,14)$, is not too effective against tabun $(6,22)$. According to our results, obidoxime seems to be more effective to eliminate tabun-induced lethal effects in mice than the oxime HI-6. Till now, it is not known what is the reason for higher effectiveness of obidoxime in comparison with the oxime HI-6. Generally, the difference between the stereochemic arrangement of obidoxime and the oxime HI-6 can play a role in the difference in therapeutic efficacy of both oximes.

The effectiveness of oximes against the toxic effects of nerve agents including tabun is usually tested in combination with atropine $(6,22,27)$. Nevertheless, some other anticholinergic drugs (e.g. benactyzine, biperiden) should be more advantageous than atropine for the elimination of toxic effects of nerve agents because of their central antimuscarinic effects $(2,13,26)$. Our results confirm the influence of anticholinergic drug selection on the efficacy of oximes in antagonizing the toxic effects of tabun at the supralethal doses. Both tested oximes, obidoxime and HI-6, were more efficacious in eliminating tabun-induced toxicity when they were combined with centrally acting anticholinergic drugs in comparison with their combination with atropine although the increase in the therapeutic efficacy of the oxime HI-6 was not significant.

Our results can be explained by the difference in the central antimuscarinic effects of anticholinergic drugs studied that are very important for the prevention of tabun-induced central respiratory depression and, thus, the survival of tabun-poisoned mice. Benactyzine, biperiden as well as scopolamine differ from atropine in that they are more potent in the central nervous system as antimuscarinics due to their relatively high affinity to the central muscarinic receptors (15) and their lipophilicity making them possible to readily cross the blood-brain barrier $(3,19,29)$. Atropine is also able to cross the blood-brain barrier but a relatively large dose of atropine is necessary to achieve the central antimuscarinic effects because of its lower lipophilicity and affinity to the central muscarinic receptors when compared to other anticholinergic drugs studied $(3,8)$.

In conclusion, our data indicate that the correct choice of AChE reactivators as well as anticholinergic drugs is important for the survival of tabun-poisoned experimental animals. The most efficacious antidotal mixture against lethal effects of tabun in mice seems to be obidoxime in combination with some of centrally acting anticholinergic drugs.

\section{Acknowledgement}

The author thanks to Mrs J. Petrová for her technical assistance and help with statistical evaluation. The study was supported by the Linkage Grant SST.CLG978.337. The author appreciates the financial support from Scientific and Environmental Affairs Division in Brussels.

\section{References}

1. Bajgar J. Present view on toxidynamics of soman poisoning. Acta Med (Hradec Králové) 1996;39:101-5.

2. Bajgar J, Fusek J, Vachek J. Treatment and prophylaxis against nerve agent poisoning. ASA Newslett 1994;94(4):10-1.

3. Bajgar J, Patočka J, Herink J, Fusek J, Hrdina V. Effect of benactyzine, atropine and chlorpromazine on blood-brain barrier permeability in rats. Act Nerv Super 1978;20:56-9

4. Cabal J, Bajgar J. Tabun - návrat po padesáti letech. Chem Listy 1999;93:27-31.

5. Clement JG. HI-6: reactivation of central and peripheral acetylcholinesterase following inhibition by soman, sarin and tabun in vivo in the rat. Biochem Pharmacol 1982;31:1283-7.

6. Clement JG, Shiloff JD, Gennings C. Efficacy of a combination of acetylcholinesterase reactivators, HI-6 and obidoxime, against tabun and soman poisoning in mice. J Chromatogr 1987;389:87-94

7. Dawson RM. Review of oximes available for the treatment of nerve agent poisoning. J Appl Toxicol 1994;14:317-31.

8. Ellenwood EHJr, Nikaido AM, Gupta SK, Heatherly DG, Nishita JK. Comparison of central nervous system and peripheral pharmacodynamics to atropine pharmacokinetics. J Pharmacol Exp Ther 1990;255:1133-8.

9. Eto M. Organophosphorus pesticides: Organic and biological chemistry. Cleveland: CRC Press Inc, 1976:p 142.

10. Jokanovic M. Anticholinesterase activity and delayed neurotoxic effects of tabun in hens. Vojvosanit Pregl 1993;50:451-6.

11. Jokanovic M, Maksimovic M, Kilibarda V, Jovanovic D, Savic D. Oxime-induced reactivation of acetylcholinesterase inhibited by phosphoramidates. Toxicol Lett 1996;85:35-9.

12. Kassa J. Comparison of efficacy of two oximes (HI-6 and obidoxime) in soman poisoning in rats. Toxicology 1995;101:167-74. 
13. Kassa J. Importance of cholinolytic drug selection for the efficacy of HI-6 against soman in rats. Toxicology 1997:116:147-52.

14. Kassa J, Cabal J, Bajgar J, Szinicz L. The choice: HI-6, pralidoxime or obidoxime against nerve agents? ASA Newslett 1997;97(4):16-8.

15. Katayama S, Ishizaki F, Yamamura Y, Khoriyama T, Kito S. Effects of anticholinergic antiparkinsonic drugs on binding of muscarinic receptor subtypes in rat brain. Res Commun Chem Pathol Pharmacol 1990:69:261-7.

16. Koplovitz I, Menton R, Matthews C, Shutz M, Nalls C, Kelly S. Dose-response effects of atropine and HI-6 treatment of organophosphorus poisoning in guinea pigs. Drug Chem Toxicol 1995;18:119-36.

17. Koplovitz I, Stewart JR. A comparison of the efficacy of HI-6 and 2-PAM against soman, tabun, sarin and VX in the rabbit. Toxicol Lett 1994;70:169-79.

18. Marrs TC. Organophosphate poisoning. Pharmacol Ther 1993;58:51-66.

19. Nakashima E, Ishizaki J, Takeda M, Matsushita R, Yokogawa K, Ichimura F. Pharmacodynamics of anticholinergic drugs and brain muscarinic receptor alteration in streptozotoxin diabetic rats. Biopharm Drug Dispos 1993;14:673-8.

20. Ohtomi S, Takase M, Kumagai F. Sarin poisoning in Japan. A clinical experience in Japan Self Defense Force (JSDF) Central Hospital. Int Rev Arm Ser 1996;69:97-102.

21. Polhuijs M, Langenberg JP, Benschop H. New method for retrospective detection of exposure to organophosphorus anticholinesterases: application to alleged sarin victims of Japanese terrorists. Toxicol Appl Pharmacol 1997;146:156-61.

22. Puu G, Artursson E, Bucht G. Reactivation of nerve agent inhibited acetylcholinesterases by HI-6 and obidoxime. Biochem Pharmacol 1986;35:1505-10.

23. Rousseaux CG, Dua AK. Pharmacology of HI-6, an $\mathrm{H}$ series oximes. Can J Physiol Pharmacol 1989;67:1183-9.

24. Tallarida R, Murray R. Manual of pharmacological calculation with computer programs. New York, Springer-Verlag:1987:p.145.
25. Taylor P. Anticholinesterase agents. In: The pharmacological basis of therapeutics (Hardman JG, Lombird LE eds.). New York, McGraw Hill:1996:p.161-76.

26. Vachek J, Kassa J, Fusek J, Bajgar J. Novějš́ způsoby léčby intoxikace organofosfáty. Sbor věd Prací VLA JEP (Hradec Králové) 1993;116:67-95.

27. Worek F, Kirchner T, Szinicz L. Treatment of tabun poisoned guinea-pigs with atropine, Hlo-7 or HI-6: effect on respiratory and circulatory functions. Arch Toxicol 1994;68:231-9.

28. Worek F, Widmann R, Knopff O, Szinicz L. Reactivating potency of obidoxime, pralidoxime, HI-6 and Hlo-7 in human erythrocyte acetylcholinesterase inhibited by highly toxic organophosphorus compounds. Arch Toxicol 1998;72:237-43.

29. Yokogawa K, Nakashima E, Ishizaki J, Hasegawa M, Kido H, Ichimura F. Brain regional pharmacokinetics of biperiden in rats. Biopharm Drug Dispos 1992;13:131-8

Submitted February 2002.

Accepted April 2002.

Doc. MUDr. Jiř̌ Kassa, CSc., P.O. Box 35/T,

Purkyně Military Medical Academy, 50001 Hradec Králové, Czech Republic. e-mail: kassa@pmfhk.cz 